\title{
Front Matter: Volume 10715
}

, "Front Matter: Volume 10715," Proc. SPIE 10715, 2017 Radioelectronic Systems Conference, 1071501 (22 May 2018); doi: 10.1117/12.2500424

SPIE. Event: Radioelectronics Systems Conference, 2017, Jachranka, Poland 


\section{PROCEEDINGS OF SPIE}

\section{Radioelectronic Systems Conference}

\section{Adam Kawalec Andrzej Witczak Editors}

\section{4-16 November 2017}

Jachranka, Poland

Organized by

Military University of Technology (Poland)

PIT-RADWAR S.A. (Poland)

The Armament Policy Department of the Ministry of National Defence (Poland) Military Institute of Armament Technology (Poland)

Sponsored by

Electronics and Telecommunications Committee of the Polish Academy of Sciences

Polish National Committee of International Union of Radio Science

Polish Space Agency

Published by

SPIE 
The papers in this volume were part of the technical conference cited on the cover and title page. Papers were selected and subject to review by the editors and conference program committee. Some conference presentations may not be available for publication. Additional papers and presentation recordings may be available online in the SPIE Digital Library at SPIEDigitalLibrary.org.

The papers reflect the work and thoughts of the authors and are published herein as submitted. The publisher is not responsible for the validity of the information or for any outcomes resulting from reliance thereon.

Please use the following format to cite material from these proceedings:

Author(s), "Title of Paper," in 2017 Radioelectronic Systems Conference, edited by Adam Kawalec, Andrzej Witczak, Proceedings of SPIE Vol. 10715 (SPIE, Bellingham, WA, 2018) Seven-digit Article CID Number.

ISSN: 0277-786X

ISSN: 1996-756X (electronic)

ISBN: 9781510619968

ISBN: 9781510619975 (electronic)

Published by

SPIE

P.O. Box 10, Bellingham, Washington $98227-0010$ USA

Telephone +1 3606763290 (Pacific Time) · Fax +1 3606471445

SPIE.org

Copyright (C) 2018, Society of Photo-Optical Instrumentation Engineers.

Copying of material in this book for internal or personal use, or for the internal or personal use of specific clients, beyond the fair use provisions granted by the U.S. Copyright Law is authorized by SPIE subject to payment of copying fees. The Transactional Reporting Service base fee for this volume is $\$ 18.00$ per article (or portion thereof), which should be paid directly to the Copyright Clearance Center (CCC), 222 Rosewood Drive, Danvers, MA 01923. Payment may also be made electronically through CCC Online at copyright.com. Other copying for republication, resale, advertising or promotion, or any form of systematic or multiple reproduction of any material in this book is prohibited except with permission in writing from the publisher. The CCC fee code is 0277 $786 \mathrm{X} / 18 / \$ 18.00$.

Printed in the United States of America.

Publication of record for individual papers is online in the SPIE Digital Library.

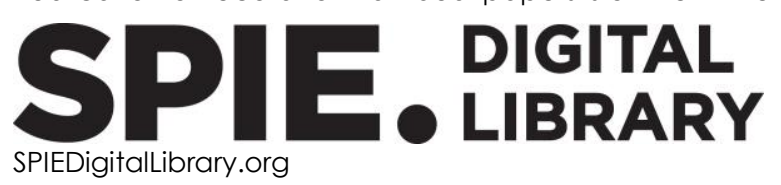

Paper Numbering: Proceedings of SPIE follow an e-First publication model. A unique citation identifier (CID) number is assigned to each article at the time of publication. Utilization of CIDs allows articles to be fully citable as soon as they are published online, and connects the same identifier to all online and print versions of the publication. SPIE uses a seven-digit CID article numbering system structured as follows:

- The first five digits correspond to the SPIE volume number.

- The last two digits indicate publication order within the volume using a Base 36 numbering system employing both numerals and letters. These two-number sets start with $00,01,02,03$, 04, 05, 06, 07, 08, 09, OA, OB ... 0Z, followed by 10-1Z, 20-2Z, etc. The CID Number appears on each page of the manuscript. 


\section{Contents}

$\checkmark \quad$ Authors

vii Conference Committee

ix Introduction

OPENING SESSION

1071502 Interception and combat of cruise missiles by Grom MANPADS [10715-4]

\section{PLENARY SESSION}

1071503 Phase difference positioning in asynchronous system [10715-14]

\section{ANTENNAS}

1071504 Analysis of conical corrugated horn antenna operating with high power pulses [10715-7]

1071505 Circular antenna array based on small cavity-backed slot antennas for wireless battlefield sensor applications [10715-16]

1071506 Numerical and experimental assessment of Vlasov antenna performance for high power microwave applications [10715-17]

BIOMEDICAL ELECTRONICS

1071507 Immunity of medical electrical equipment to radiated RF disturbances [10715-18]

1071508 Spectral analysis of major heart tones [10715-9]

MICROWAVES AND OPTOELECTRONICS TECHNOLOGIES

1071509 Parasitic modes in oven magnetron [10715-5]

10715 OA Noise analysis in numerical modeling of crossed fields microwave tubes [10715-13] 


\section{RADIOLOCATION IN APPLICATIONS}

$10715 \mathrm{OB}$ Evaluation of jamming efficiency for the protection of a single ground object [10715-2]

$107150 \mathrm{C}$ A method to improve the range resolution in stepped frequency continuous wave radar [10715-3]

10715 OD Acoustic direction finding using multi-dimensional Fourier transform [10715-10]

$10715 \mathrm{OE}$ Ground penetrating radar data processing using Akaike information criterion [10715-25]

\section{SIGNAL AND DATA PROCESSING IN RADIOELECTRONICS SYSTEMS}

10715 OF Fusion of identification information from ELINT-ESM sensors [10715-1]

10715 OG The concept of the radar environment simulator software [10715-22]

$10715 \mathrm{OH}$ Optimization of the efficiency of search operations in the relational database of radio electronic systems [10715-20]

$10715 \mathrm{Ol}$ Matched filter module as an application of modern FPGA in radar systems [10715-26]

10715 0J Application of CUDA computing technology for digital antenna beam forming [10715-24]

\section{TELEDETECTION}

10715 OK High-speed object detection methods [10715-8]

$10715 \mathrm{OL}$ Azimuth estimator for a rotating array radar with wide beam [10715-23]

\section{TRANSMIT AND RECEIVE MODULES}

$107150 \mathrm{M}$ Ammonothermal GaN substrates for microwave electronics and energoelectronics [10715-28]

10715 ON GaN HEMT power amplifier for radar waveforms [10715-27] 


\section{Authors}

Numbers in the index correspond to the last two digits of the seven-digit citation identifier (CID) article numbering system used in Proceedings of SPIE. The first five digits reflect the volume number. Base 36 numbering is employed for the last two digits and indicates the order of articles within the volume. Numbers start with 00, 01, 02, 03, 04, 05, 06, 07, 08, 09, OA, OB...0Z, followed by 10-12, 20-2Z, etc.

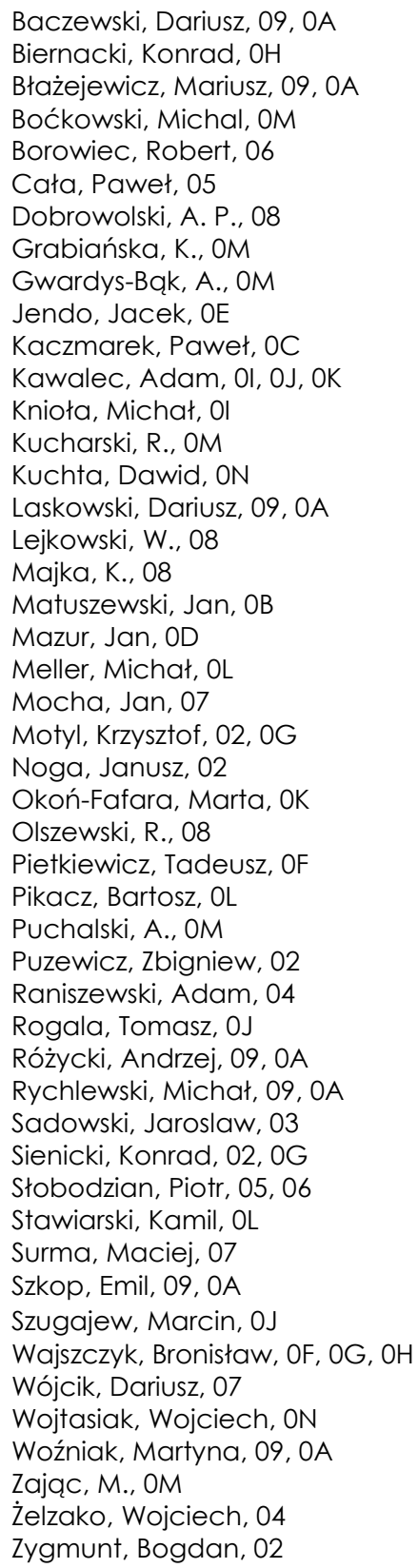


Proc. of SPIE Vol. 10715 1071501-6

Downloaded From: https://www.spiedigitallibrary.org/conference-proceedings-of-spie on 25 Apr 2023 Terms of Use: https://www.spiedigitallibrary.org/terms-of-use 


\title{
Conference Committee
}

\author{
Conference Chairs
}

Adam Kawalec, Military University of Technology (Poland) Krzysztof Kulpa, Warsaw University of Technology (Poland) Robert Szelenbaum, PIT-RADWAR S.A. (Poland)

Andrzej Witczak, Military University of Technology (Poland)

Scientific Committee

Witold Czarnecki, Military University of Technology (Poland) Andrzej Dobrowolski, Military University of Technology (Poland) kukasz Dziuda, Military Institute of Aviation Medicine (Poland) Jerzy Kopatka, Military University of Technology (Poland) Paweł Kabacik, Wroclaw University of Technology (Poland) Piotr Kaniewski, Military University of Technology (Poland) Ryszard J. Katulski, Gdansk University of Technology (Poland) Mieczysław Lepionka, Polish Space Agency (Poland) Zygmunt Mierczyk, Military University of Technology (Poland) Jerzy Miłosz, PIT-RADWAR S.A. (Poland) Jacek Misiurewicz, Warsaw University of Technology (Poland) Józef Modelski, Warsaw University of Technology (Poland) Marek Nałęcz, Warsaw University of Technology (Poland) Mateusz Pasternak, Military University of Technology (Poland) Edward Sędek, PIT-RADWAR S.A. (Poland)

Piotr Slobodzian, Wroclaw University of Technology (Poland) Bogusław Smólski, Military University of Technology (Poland) Cezary Specht, Gdynia Maritime University (Poland) Waldemar Susek, Military University of Technology (Poland) Bronisław Stec, Military University of Technology (Poland) Wojciech Wojtasiak, Warsaw University of Technology (Poland) Ewelina Zawadzka-Bartczak, Military Institute of Aviation Medicine (Poland)

Session Chairs

Plenary Session I

Andrzej Dobrowolski, Military University of Technology (Poland) Adam Kawalec Military University of Technology (Poland)

Microwave and Optoelectronic Technologies I

Waldemar Susek, Military University of Technology (Poland) 
T/R Modules

Wojciech Wojtasiak, Warsaw University of Technology (Poland)

Microwave and Optoelectronic Technologies II

Bronisław Stec, Military University of Technology (Poland)

Waldemar Susek, Military University of Technology (Poland)

Antennas

Piotr Slobodzian, Wroclaw University of Technology (Poland)

Signal and Data Processing in Radioelectronic Systems I

Krzysztof Kulpa, Warsaw University of Technology (Poland)

Jerzy Kopatka, Military University of Technology (Poland)

Unmanned Aerial Vehicles: Construction, Use, Detection, and Combating I

Andrzej Witczak, Military University of Technology (Poland)

Plenary Session II

Bogusław Smólski, Military University of Technology (Poland)

Unmanned Aerial Vehicles: Construction, Use, Detection, and Combating II

Witold Czarnecki, Military University of Technology (Poland)

Biomedical Electronics

Zygmunt Mierczyk, Military University of Technology (Poland)

kukasz Dziuda, Military Institute of Aviation Medicine (Poland)

Company Session

Andrzej Witczak, Military University of Technology (Poland)

Signal and Data Processing in Radioelectronic Systems II

Ryszard J. Katulski, Gdansk University of Technology (Poland)

kukasz Dziuda, Military Institute of Aviation Medicine (Poland)

Radar Applications I

Jerzy Milosz, PIT-RADWAR S.A. (Poland)

Mateusz Pasternak, Military University of Technology (Poland)

Remote Sensing

Adam Kawalec Military University of Technology (Poland)

Krzysztof Kulpa, Warsaw University of Technology (Poland)

Radar Applications II

Mateusz Pasternak, Military University of Technology (Poland) 


\section{Introduction}

The annual Radioelectronic Systems Conference supports a detailed discussion of the most important technical issues in the field of radioelectronic systems. It is also a review of the country's work and direction in radioelectronic technologies.

A rapid development of new signal processing algorithms and methods have emerged, along with new technologies that allow us to introduce advanced technical solutions into radioelectronic systems.

A mutual exchange of experience between national scientific centres, research and development units, and the national electronics industry should result in cooperation that is a key factor for successful development of radioelectronic systems.

Every year, the conference expands its topics spectrum according to the expectations of the community.

This year, the scope of the conference included:

- Acoustics and Acoustoelectronics

- Antennas and Microwaves

- Use of Unmanned Aerial Vehicles and Defence against Unauthorized Use

- Biomedical Electronics

- Optoelectronics

- Signal and Data Processing in Radioelectronic Devices and Systems

- Radar Systems

- Navigation Systems

- Radioelectronics in Space Applications

- Special Devices and Systems.

The conference is organized under the auspices of the Ministry of National Defence, which emphasizes the fact that the scope of the conference covers the priorities of the Polish Armed Forces.

We hope that the 2017 Radioelectronic Systems Conference was the basis for indepth discussion among participants and a great opportunity to exchange knowledge and experience.

Adam Kawalec Andrzej Witczak 
Proc. of SPIE Vol. 10715 1071501-10

Downloaded From: https://www.spiedigitallibrary.org/conference-proceedings-of-spie on 25 Apr 2023 Terms of Use: https://www.spiedigitallibrary.org/terms-of-use 